CP, 2016, Vol.5 - No10, pp. 71-85. ISSN 2014-6752. Girona (Catalunya). Universitat de Girona. SUBIELA HERNÁNDEZ, BJ., MARTíNEZ SÁNCHEZ, J. Y HERNÁNDEZ GÓMEZ, F. : Social network penetration and usage amongst people over 64 years of age. Recibido: 14/11/2016 - Aceptado: 21/11/2016

\title{
Social network penetration and usage amongst people over 64 years of age
}

\section{Penetración y usos de redes sociales entre la población mayor de 64 años}

\author{
Autores \\ Blas José Subiela Hernández \\ http://orcid.org/0000-0002-7540-9260 \\ Universidad Católica de Murcia \\ Jesús Martínez Sánchez \\ http://orcid.org/0000-0002-6090-711X \\ Universidad Católica de Murcia \\ Francisco Hernández Gómez \\ http://orcid.org/0000-0002-1021-7604 \\ Universidad de Murcia
}

\section{ABSTRACT}

The Internet and social networks, currently considered a generic asset for most social groups, have become increasingly popular as they are easy to use and help to create and maintain relationships. However, there are still some age groups in which the use of the Internet and social networks is still in its early stages. More specifically, we are referring to people over the age of 64 , who are the most affected by the generational and digital gap when it comes to the use of new technologies. This study looks into the perceived level of Internet and social network penetration and knowledge within this segment of the population, in addition to identifying their usage habits and access barriers. To do that, we have carried out a cross-sectional ad-hoc survey through stratified, proportional sampling and probabilistic allocation to a group of 390 individuals registered in the municipality of Murcia. Survey results coincide with former studies

\section{RESUMEN}

Internet y las redes sociales son en la actualidad un bien genérico para la mayoría de los grupos sociales. Su facilidad de uso y su capacidad para generar y mantener relaciones han contribuido a su generalización. No obstante, siguen existiendo determinados segmentos de edad en los cuales su introducción está todavía en fases iniciales. Nos referimos a los mayores de 64 años, a los cuales la brecha generacional y digital les está afectando en cuanto al uso de las nuevas tecnologías. Este estudio analiza el nivel percibido de penetración y conocimiento de Internet y redes sociales en este segmento de población, además de identificar los hábitos de uso de estas herramientas y las barreras de acceso que les afectan. Para ello, hemos realizado una encuesta ad hoc transversal, mediante muestreo probabilístico estratificado y afijación proporcional, a una muestra de 390 individuos empadronados en el municipio de Murcia. Los 
as they confirm the low penetration of these computational platforms amongst senior citizens. Results also show the interest of this age group to get training and information with the aim to start using them. Thus, public administrations need to address this situation by implementing policies intended to favor ICT integration into the daily lives of people over the age of 64 .

KEYWORDS: Digital communication, education and socialization, interactive tools, Internet, Seniors, Social Networking, ICT, Internet use

\section{INTRODUCTION AND STATE OF THE}

\section{ART}

It is a fact that the age pyramid of Spain is gradually aging. According to Spain's National Institute of Statistics (2012-2052), there are currently almost 8.5 million senior citizens aged over 65 , a number that will increase to over 15 million in 2050, year when the UN estimates that in 2050, Spain will be the country with the oldest population worldwide, with $34.5 \%$ of its citizens aged over 65 (Aunión, 2014). This prospect, together with the rise of social networks, justifies the need for this study as a way to determine the link between social media and senior citizens over 64 years old.

For the purpose of this study, social networks are Internet services allowing users to create a public profile with personal information and to interact with other web users who may or may not have a similar profile (Freire, 2013). Our study will focus on the use of platforms including Facebook, Twitter and WhatsApp. The proliferation of mobile devices has provided people between the ages of 56 and 81 with the opportunity to communicate via social networks such as WhatsApp, an application which is easing out traditional telephone communication (Llorente, Viñarás \& Sánchez, 2015). In Spain, fourth country worldwide in terms of WhatsApp usage (Marketingdirecto, resultados coinciden con estudios previos al constatar la escasa penetración de estas plataformas de comunicación entre los mayores. Sin embargo, ponen de manifiesto el interés de este grupo de edad por formarse e informarse para comenzar a utilizarlas. $Y$, por tanto, la necesidad de que las administraciones públicas aborden esta situación con políticas de integración de las TIC en la vida cotidiana de los mayores de 64 años.

PALABRAS CLAVE: Comunicación digital, Educación y socialización, Herramientas interactivas, Internet, Mayores, Redes sociales, TIC , Uso de internet

2014) behind Malaysia (77\%), South Africa and Singapore (76\%), $75 \%$ of the population has a smart phone. According to data supplied by the National Commission on Markets and Competition (2015), 94\% of Spanish citizens owning a smart phone access mobile messaging applications such as WhatsApp and Line, among others. Although only $12.1 \%$ of people aged over 64 have a smart phone with Internet connectivity, which is theoretically the main access gate to this virtual social network, their use of Whatsapp is quite intense (Llorente, $\mathrm{Vi}$ ñarás \& Sánchez, 2015). This study aims to compare these general data and our target population segment.

Many and varied research projects have been undertaken to learn more about the access and use of information and communication technologies by people over the age of 50 (Padilla-Góngora \& Padilla-Clemente, 2008; Agudo, Pascual \& Fombona, 2012; González et al., 2012; Lelkes, 2012; Leist, 2013; González et al., 2015; Llorente et al., 2015; Casado, Lezcano \& Rodríguez, 2015; Colombo, Aroldi \& Carlo, 2015; Peral, Arenas \& Villarejo, 2015). However, the age group over the age of 64 has received little attention, most likely because the percentage of users at this age is quite low. The 
age-segmented data supplied by the $\mathrm{Na}$ tional Observatory for Telecommunications and the Information Society on December 2011 do not take users older than 54 into consideration. It also reveals that as user age increases, usage frequency decreases. That means that the use of social networks amongst the last age segment included (4554 years) is a mere $49 \%$, much less than the $80 \%$ of the $18-24$ age group (ONTSI, 2011). The data provided by Fundación Telefónica (2012) shows that only $0.8 \%$ of citizens over the age of 65 use these technologies to communicate with friends and family. González et al. (2015) point out that only $3 \%$ of individuals over the age of 55 think of themselves as users and $15 \%$ have used them at some point. Fundación Vodafone España (2012) is the only organization providing info relating to a universal sample similar to ours: $21.2 \%$ of Murcian Internet users with ages between 56 and 65 make regular use of some social network.

However, INE statistics (2011-2014) on Household Information and Communication Technologies Equipment and Usage shows a gradual, steady growth in the number of people aged 65-74 who use the Internet regularly. With regards to this, in 2011 that percentage was $16.2 \%$, significantly lower than the $26.2 \%$ recorded in 2014 . According to data from last year, $33.4 \%$ of Internet users were also social network users.

These figures tend to converge, slowly and heterogeneously, with those of other G20 countries. As a comparison index, in 2014 French seniors accounted for $24.1 \%$ of Internet users (González et al., 2015), percentage that went up to $34.4 \%$ in Italy (Colombo et al., 2015) and 50\% in the United States, where one in every three (34\%) senior citizens are connected to the social networks (Leist, 2013: 379). In the same vein, the study Demographics of Key Social Networking Platforms by the Pew Research Center (2015) reveals that $10 \%$ of USA Internet users aged 65 and older use Twitter regularly. It could be said that the elderly are late ICT adopters rather than pioneers (Chen \& Chan, 2014). In addition to the limited research related to social networks and Internet usage amongst senior citizens, the research available is mostly focused on aspects relating to their wellbeing (González et al., 2012; Cristóbal, Daries \& Baldomar, 2014; CasteIlano, 2014; Colombo et al., 2015; Llorente et al., 2015; Casado et al., 2015). Some authors (Padilla-Góngora \& Padilla-Clemente, 2008; Cárdenas, Melenge, Pinilla, Carrillo \& Chaparro, 2010; Leist, 2013; Chen, Lee \& Kirk, 2013) have proven that maintaining virtual social relationships is vital to have a good mental and physical state of being, especially at a later age. In today's society, with an increasing number of senior citizens living alone every year, virtual social networks could help these individuals open up to other people and interact. However, it is important to mention studies on the use, consumption and knowledge of new technologies amongst senior citizens beyond e-health limits (González et al., 2105; Peral et al., 2015; Luna, Mendoza \& Álvarez, 2015; Sánchez, Kaplan \& Bradley, 2015). This research is intended not only to gain knowledge on social network and Internet usage within this age group, but also to find out the reasons behind the low usage percentages shown by national studies and to detect usage barriers and habits in the use of these applications for senior people. In order to ensure research results are statistically representative, our study population is limited to the municipality of Murcia, as explained in the "material and methods" section. Data regarding ICT use by Murcia citizens is limited to the information provided in the Household Information and Communication Technologies Equipment and Usage Survey (2011-2014) by INE and Fundación Telefónica (2013). According to INE, the number of citizens accessing the Internet over the last three months of 2014 compared to 2013 was stable at $73 \%$, of whom $67.2 \%$ were present in the social networks.

During the last four years (2010-2014) multiple projects intended to facilitate the access 
of people over the age of 64 to virtual communities and to favor their re-integration into the social sphere through online community participation, have been developed. An example of this is TAO (Third Age Online), a project funded within the EU-program Ambient Assisted Living and intended to promote the participation of senior citizens in online communities and to favor their social integration in a sustainable manner.

With regards to the Region of Murcia, although a number of public initiatives were launched in an attempt to reduce the digital gap, none of importance facilitating social network and Internet access and usage by senior citizens was undertaken during the last five years. This can be seen in the Information Society reports issued by Fundación Telefónica from 2010 to 2014 (drafted together with the different Spanish Regions). Having said that, some of the projects completed, although not specific for our target age group, did provide information regarding their needs, especially in terms of health.

\section{MATERIAL AND METHODS}

This work was developed through single-phase research which was descriptive, cross sectional and quantitative.

The main objective of this research is to study how people over the age of 64 in the municipality of Murcia access new communication technologies with the aim of proposing social integration policies adapted to their specific profile.

In order to achieve the main objective, the following specific objectives are developed:

1. Determine the level of Internet and social network penetration and knowledge within our study target population. By "penetration" we refer to the use they make of these infrastructures.

2. Describe social network and Internet usage in terms of frequency, type of device used, place of access and activities carried out.

3. Identify and prioritize social ne- twork and Internet access barriers in our STP.

We have used mainly two methodologies to prepare this work. Firstly, we have analyzed secondary sources so as to detect similar studies and references. Secondly, we have developed the survey as a research technique favoring the creation of primary information. More specifically, we have carried out a cross-sectional ad-hoc survey through stratified, proportional sampling and probabilistic allocation. This research may ultimately be turned into a wide-ranging survey. The specific data can be seen in the following fact sheet. 


\begin{tabular}{|l|l|}
\hline \multicolumn{2}{|l|}{ SPECIFICATION Survey for people over the age of 64 registered in the municipality of Murcia } \\
\hline \multirow{2}{*}{ Technique used } & $\begin{array}{l}\text { SURVEY through stratified, proportional sampling and probabilistic allocation to } \\
\text { people over the age of } 64 \text { registered in the municipality of Murcia. }\end{array}$ \\
\hline \multirow{2}{*}{$\begin{array}{l}\text { Field work } \\
\text { Population (STP). }\end{array}$} & $\begin{array}{l}\text { Seople of both sexes over the age of } 64 \text { and registered in the municipality of } \\
\text { Murcia when the field work was carried out. }\end{array}$ \\
\cline { 2 - 3 } Action framework & Municipality of Murcia. \\
\hline STP quantification & 64,219 people (INE, 2014). \\
\hline Sample size & 390 interviews. \\
\hline Sampling & Stratified probability \\
\hline Allocation & Proportional. \\
\hline Sampling error & $\begin{array}{l}\text { E }= \pm 5.0 \%, \text { for the "total" column, assuming simple, random sampling criteria for } \\
\text { maximum indetermination cases }[P \text { (phenomenon probability) }=Q\end{array}$ \\
\hline (complementary probability) $=50 \%]$ and a confidence level of $95.5 \%$ (k=2).
\end{tabular}

A number of methodologies were used within this questionnaire. One of them was the 10-position Likert scales meeting the following conditions (Dillon, Madden \& Firtle, 1996): they include all key object attitude aspects, prevent formulation ambiguity and are sufficiently efficient to discriminate interviewees in relation to the researched attitude. Furthermore, these scales were vali- dated using the Cronbach Alpha coefficient, which in this case is above 0.75 for each attribute (comprised of specific attribute items). For Malhotra (2011) the Cronbach Alpha coefficient varies from 0 to 1 , with a value $\geq 0.6$ indicating satisfactory internal consistency reliability. The information included in the following table was considered in this validation. 


\begin{tabular}{|l|l|}
\hline SCALE DESIGN & EFFECT ON RELIABILITY \\
\hline Number of items & Reliability increase \\
\hline Item difficulty & No evidence exist one way or another \\
\hline Type of scale & There is no a priori superiority of a multi-item scale over another \\
\hline Number of categories & As it increases, reliability improves too \\
\hline Scale format & There is no evidence that colors, graphs, etc. impact reliability \\
\hline $\begin{array}{l}\text { Scales with neutral } \\
\text { categories (indifferent) }\end{array}$ & There is no evidence of its influence on reliability \\
\hline Source: Own development. Grande \& Abascal, 2011. \\
\hline
\end{tabular}

Questionnaires were written using simple language so as to facilitate understanding by respondents, especially considering their diverse ages and academic backgrounds. These diversity factors are mentioned in a number of works (Gracia \& Herrero, 2008; Imserso, 2011). Test contents are related to common indicators on ICT presence in the Spanish society (Gracia \& Herrero, 2008). We have used a structured questionnaire with closed variables in which suggested response options were random with the aim of preventing inertias and vices.

Lastly, we included six variables for socio-demographic segmentation of our STP: age window, place of residence, sex, marital status and level of education.

In order to control and validate the questionnaire, a pretest was handed over to a group of 50 individuals in the final sample. A thorough review of secondary sources with the aim of checking other questionnaires used and applied to our STP, was also carried out.

The data obtained through the survey was used to put together the following statistical treatments:

- Multiple linear regression.

- Discriminant analysis.
- ANOVA.

- Contingency tables (chi2).

- Marginals.

However, many results are not presented due to a lack of statistical representativeness. With regards to this, out of the bivariate analysis corresponding to contingency tables, we have considered results with a chi2 being $<0.05$.

Our target will be senior citizens over the age of 64 who are registered in the metropolitan area of Murcia, the seventh most populated city in Spain. Murcia does not have the 3.1 or 1.6 million citizens of large cities such as Madrid and Barcelona, but it is above the national average in Spain. Within the municipality of Murcia, $14.6 \%$ of its more than 430,000 inhabitants are aged over 64 (total: 64,219). As for sex distribution, $42.3 \%$ men and $57.7 \%$ women. These data are comparable to the distribution in the rest of the country: $18 \%$ of all inhabitants, $42.8 \%$ men and $57.2 \%$ women (INE, Municipal register on January 2014).

Internet penetration amongst STP members is not high yet compared to that of younger age groups: $53.6 \%$ say they have no Internet connection, mainly because they do not properly know how to use it. This information is closely related to the fact that a high 
percentage of these senior people never connect to the Internet (74.8\%). It is interesting that $27 \%$ of individuals who do have access to the Network, do not use it.

If we look at those who do use the Network, the most common user profile is a woman aged 65 to 74, married, university undergraduate and resident in the urban center.

As for the number of times they access the Internet, the average is 23 times per month. With regards to sex, level of education and place of residence, there are no significant differences.

The devices most commonly used to access the Network are cell phones (62.9\%) and desktops (47.7\%). It is also important to mention the low use of two connection devices which have become recently popular: tablets (18.9\%) and Smart TVs (2.35\%). This shows that the versatility of cell phones has surpassed the connectivity advantages of remaining devices.
The STP accesses the Internet from home (29.5\%) and without consideration for using hours (20.3\%). This basic datum seems to contradict what was mentioned before regarding smart phone mobility, especially considering that the second most popular place for accessing the Network is cafeterias and restaurants, although with a percentage much lower (7.9\%) than that of households.

The main activities of our STP in the Internet are the communication with family and friends and the search for information, way ahead of entertainment, leisure and handling administrative processes and procedures. These uses differ from those presented by Casado et al. (2015), mainly emails, search for information and reading the press. This difference makes sense because the abovementioned study refers to a period when SN were not developed yet (2004-2012).

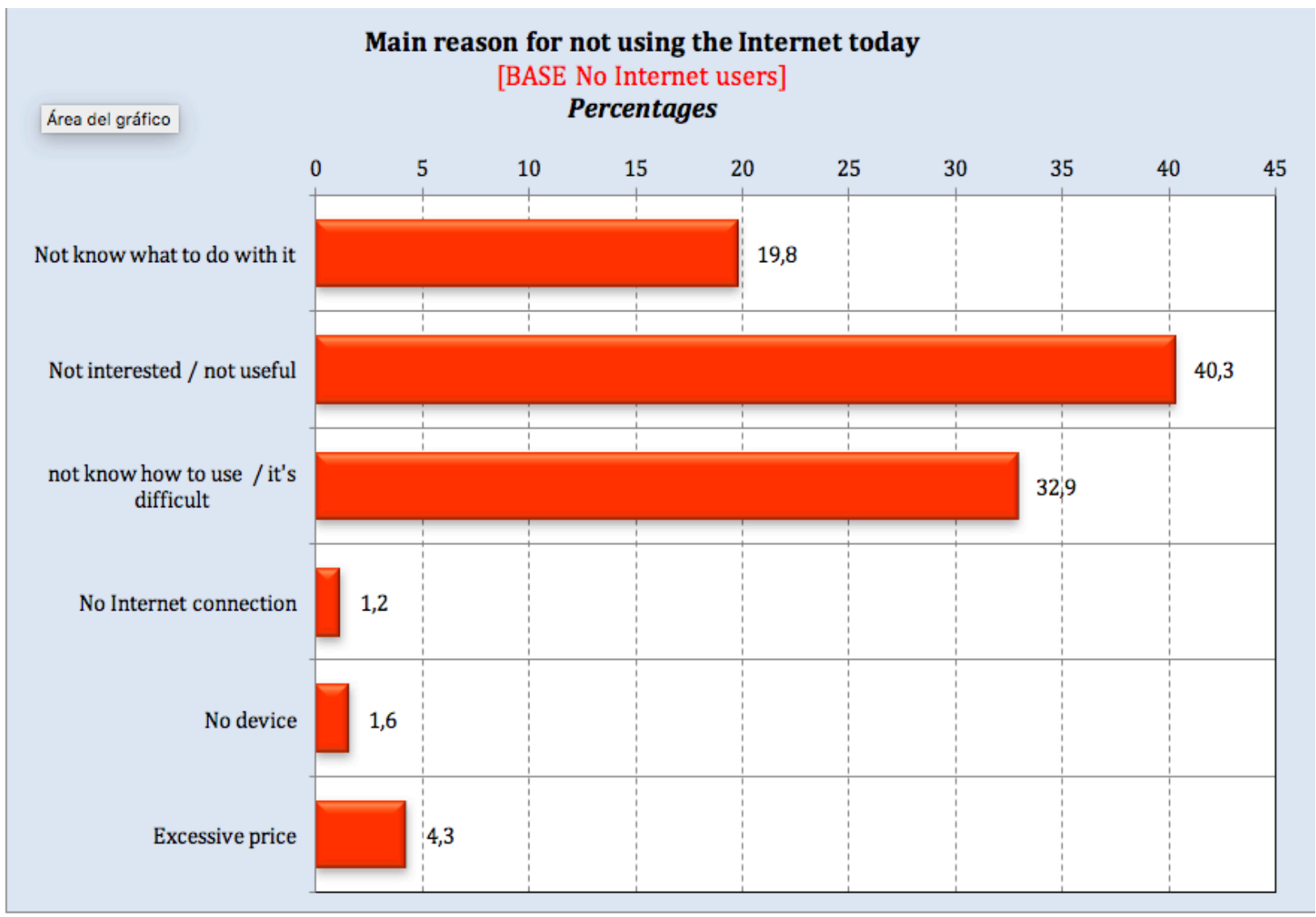


As for Internet usage barriers, there are two aspects to consider: one is pragmatic and relates to the little or no interest they have on this technology, and the other is functional, because they do not know how to use it and think of it as something quite difficult to learn. These two aspects have a significant impact on their hesitation to use this ICT in the future. At this point, we find a certain level of correlation with the data provided by Observatorio Fundación Vodafone-CERMI (2011), which showed that the main reason for the low usage of this technology was a lack of motivation, related to the difficulty in seeing its real value and to functional and economic limitations.

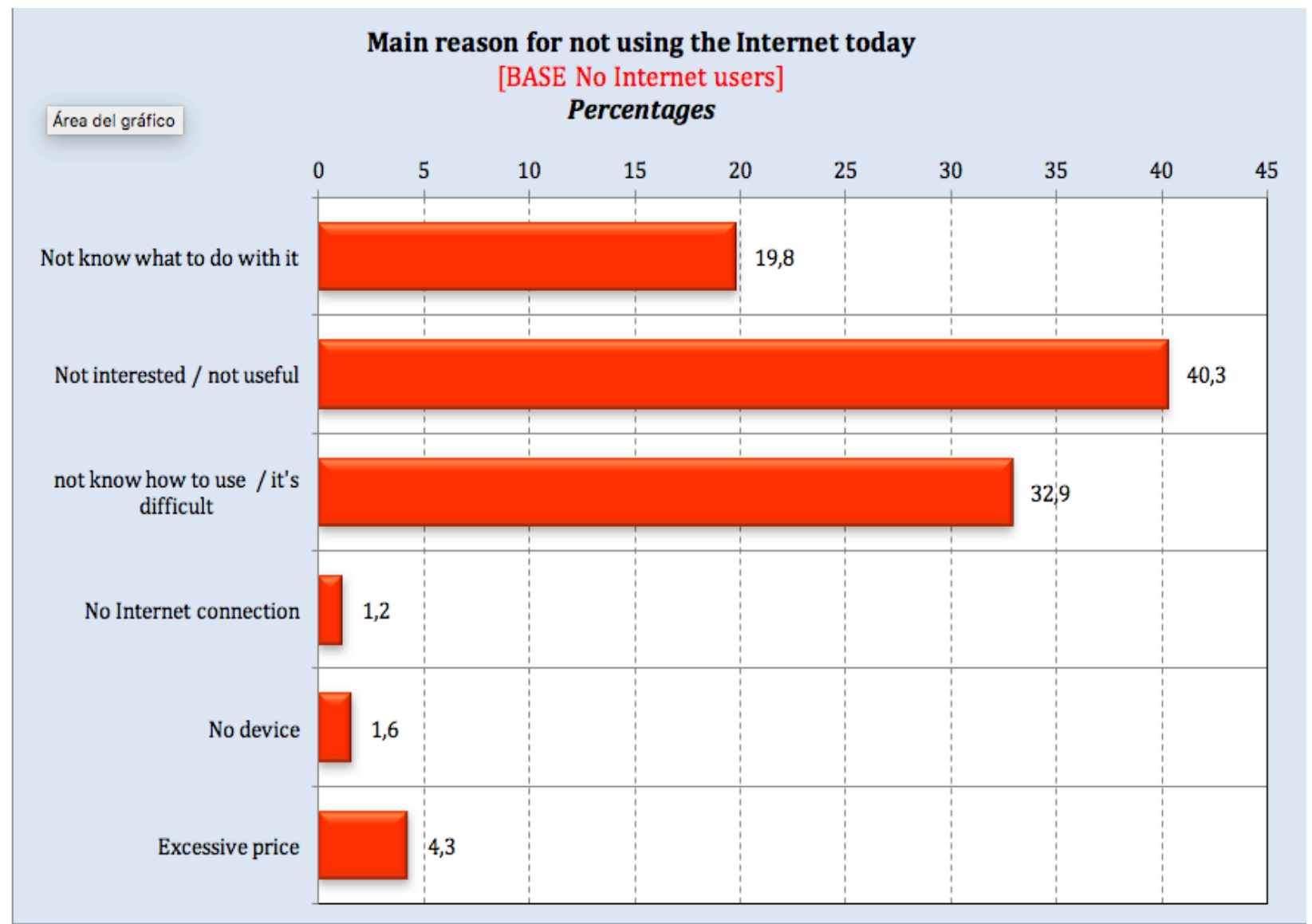

There are various arguments used as a basis for people their age to start using the Internet, mainly the desire for more information and training on the advantages, usability and operation of these technologies $(17.2 \%$ and $14.9 \%$, respectively) and a reduction in household connection fees (14.9\%).

With regards to the penetration of social networks in our target population, it is worth mentioning the following results. A total of $27.4 \%$ state they know some social network and $23 \%$ say they use them. We can establish a nearly direct correlation between $\mathrm{SN}$ knowledge and their use. However, that re- lationship is not so clear between the use of the Internet (36.7\%) and SN (23\%). Over $13 \%$ of Internet users do not use SN.

There are no significant differences with regards to SN knowledge between men and women. Having said that, women use them more actively than men. Some $75.4 \%$ of women using the Internet also use SN, whereas in the case of men that percentage goes down to $60.3 \%$.

As for their place of residence, $\mathrm{SN}$ are most widely known and used in urban centers (91.5\% of knowledge and $75.6 \%$ of usage) 
than in districts $(64 \%$ and $56 \%$ respecti- that the higher the level of education, the vely). There are no significant differences in greater the use of these technologies, as terms of marital status. It is also confirmed seen in the following graph.

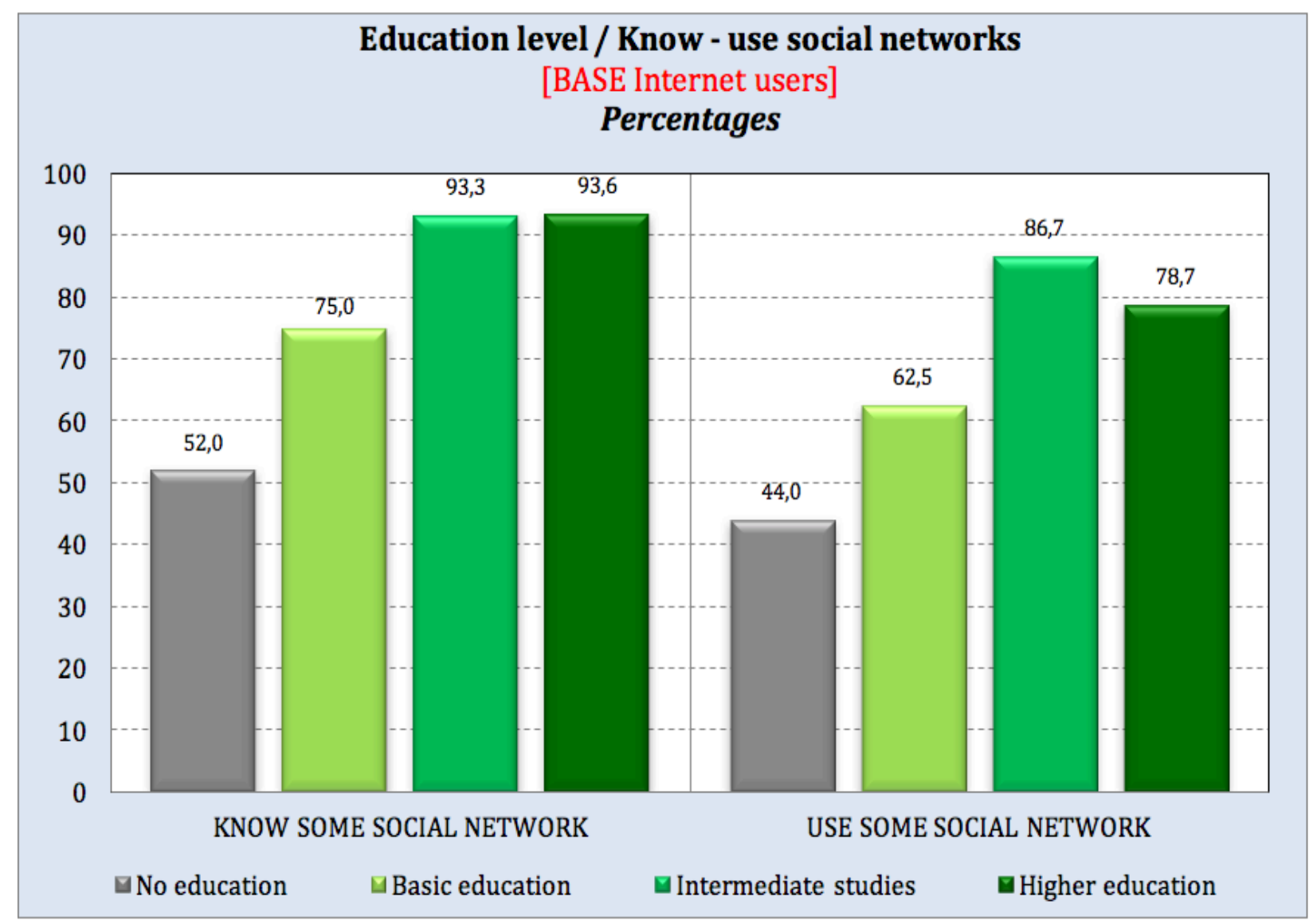

Thus, the average SN user profile in our STP is a women residing in the urban center and with a high level of education, similar to what was mentioned for Internet users.

As for the frequency of usage, most users (72.2\%) access SN on a daily basis, with only $6.7 \%$ accessing less than once per day. They also access at any time of the day $(71.7 \%)$ and mostly using their cell phone (84.4\%). Other devices, computers inclu- ded, are less commonly used. SN are accessed via a desktop by $24.4 \%$ of our population, from a laptop by $15.6 \%$ and from a tablet by $18.9 \%$.

Nearly all users (96.7\%) say they use social networks mainly to connect with families and people they know. The following graph shows that other motives for usage are not nearly as significant. 


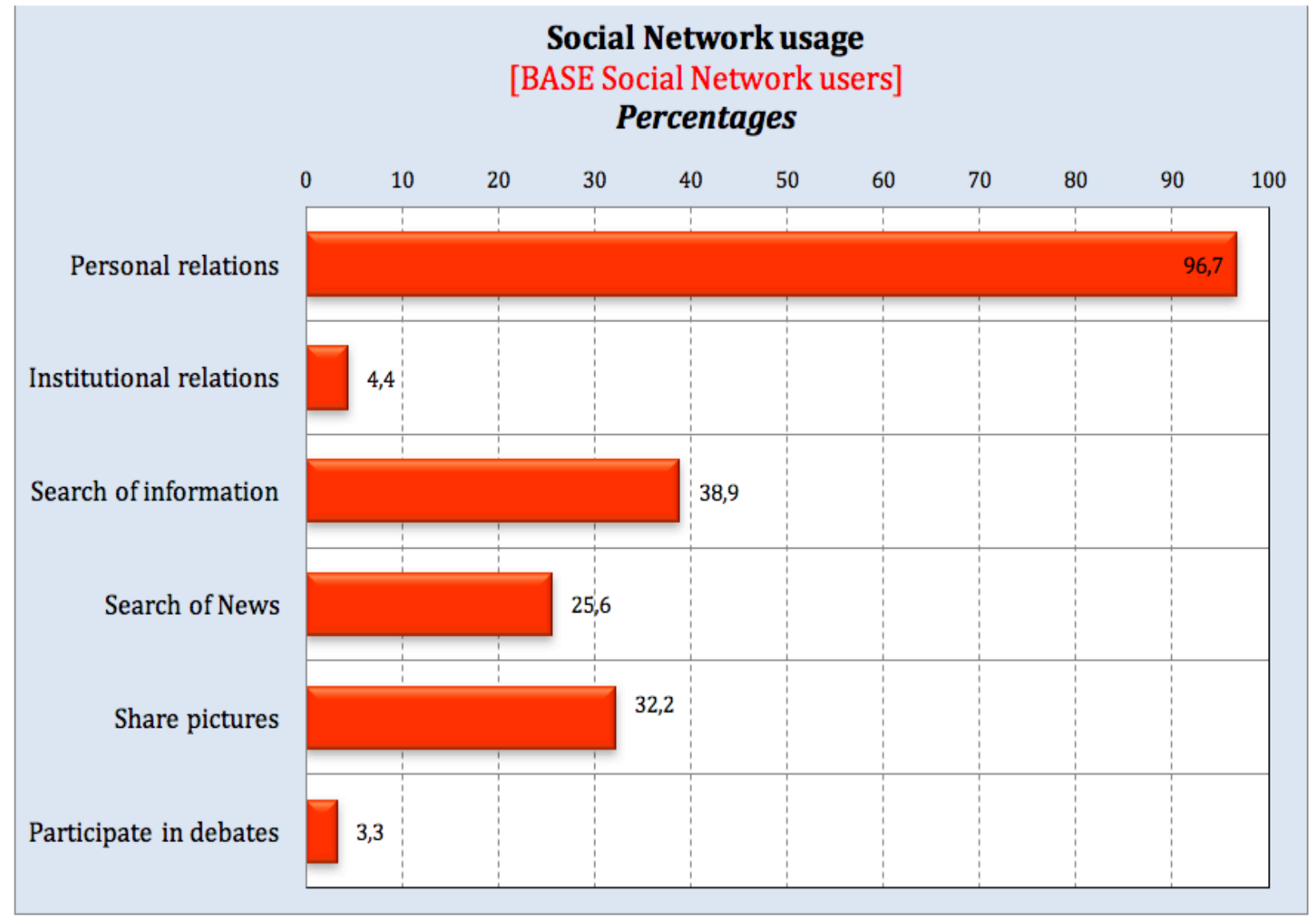

The most commonly known and used network is the Instant Messaging network Whatsapp, with $85.6 \%$ of all users, followed by Facebook with a much lower $40 \%$ of

penetration among our STP. The following graph provides detailed information on user distribution amongst the main social networks.

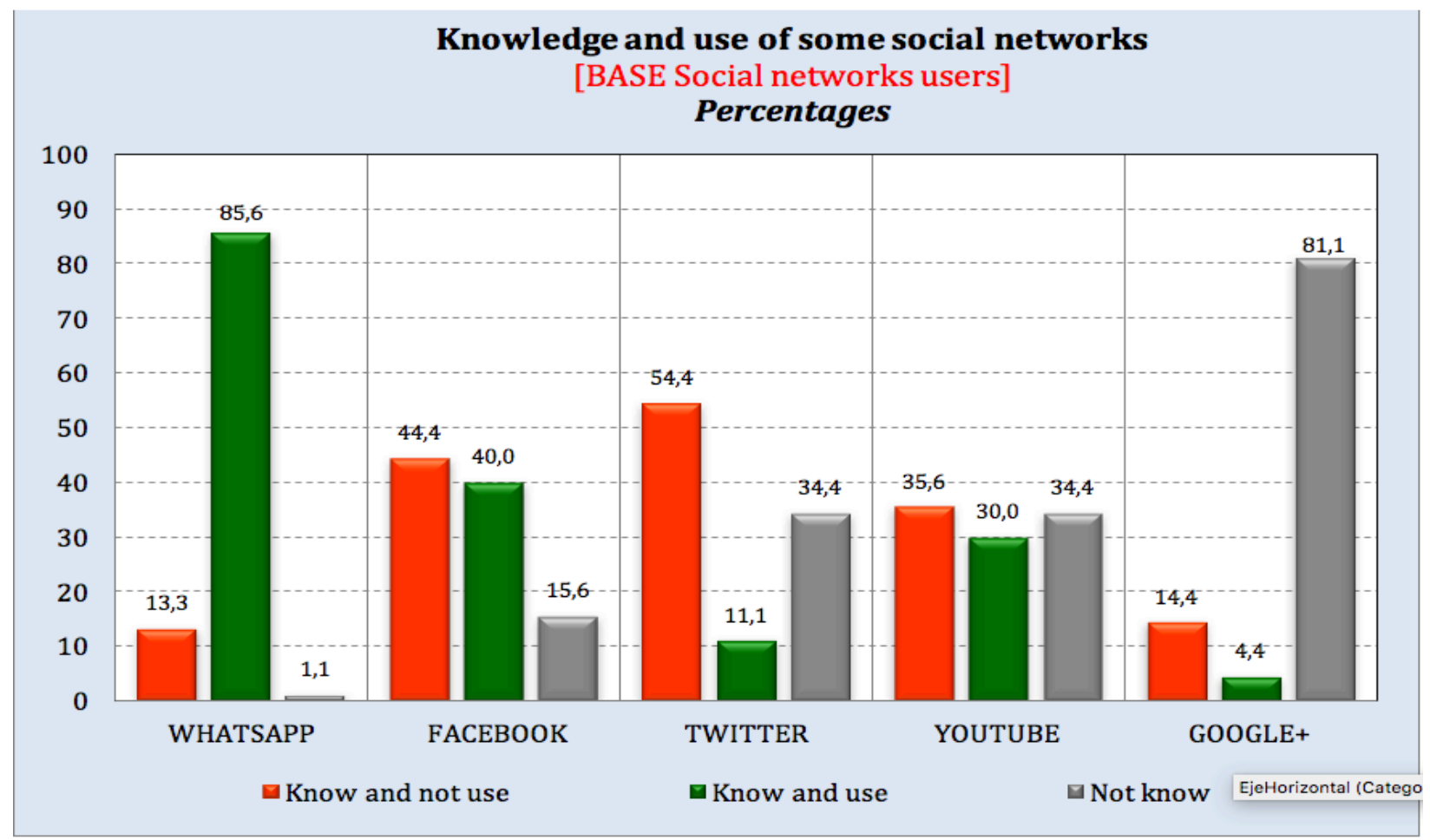


As for the way in which SN were heard about, most say they learned about them through family and friends (90\%), with only $4.4 \%$ saying they knew about them through training courses. An even lower 2.2\% of users stated that they heard about SN through the media.

With regards to the perceived level of knowledge on SN usage, it is worth mentioning that a remarkable percentage of users $(22.4 \%)$ believes they have no knowledge of SN usage whatsoever, although they still think of themselves as users. Having said that, more than half (55.3\%) say their level of knowledge is medium or high.
As for SN non-users who do have Internet access, the main reason why they do not access these networks is their lack of interest and their perception that they are not useful (43.8\%); a large percentage of them also mention they do not know how they work (39.6\%). In any case, their perception of SN being dangerous for their intimacy is quite low (6.3\%), although when asked about ways to facilitate their SN access, most respondents referred to training $(45.2 \%)$, followed by information (1) (33.3\%). Cheaper Internet connection fees are only an issue for $14.3 \%$, whereas aspects such as the creation of public access spaces and free-of-charge public connections are only mentioned by a small low percentage (4.8\% and $2.4 \%$ ).

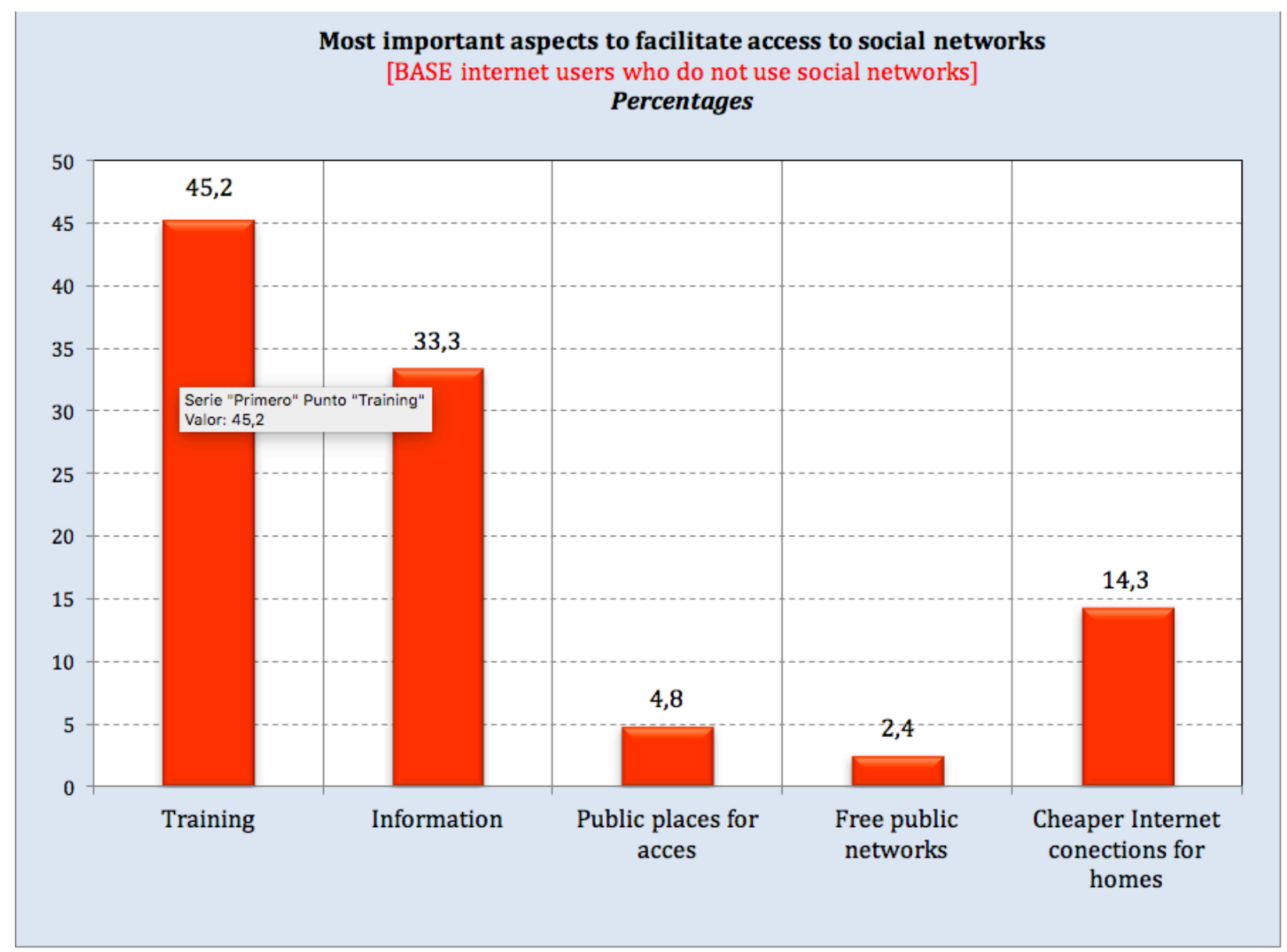

\section{DISCUSSION AND CONCLUSIONS}

The first surprising finding in this research was the lack of knowledge of our STP of SN and Internet operation. More specifically, pretest interviewees responded they did not utilize the Internet, although when asked about WhatsApp, they said they used it. That means they were using the Internet through this application without knowing it; as a result, we needed to change the questionnaire. 
Another important finding illustrating technological ignorance is the low percentage of people who have and use the Internet connection, especially when compared with the rest of age profiles. Actually, over $25 \%$ of individuals with access to the Internet do not use it. Therefore, a significant educational exercise is required in this population group with no access barrier resulting from device or connection fee limitations, but still not daring to use the Internet because they think their knowledge is insufficient or the net is not useful.

In the specific case of SN usage, the findings are similar to those that apply to Internet usage. Over $10 \%$ of Internet users do not use SN. Once again, we are talking about a group with no barriers regarding their devices or connection access which does not use SN because they do not know their functionalities.

These data show that our STP is not interested in the Internet and SN because they do not think these are useful and perceive the need to develop skills which they lack. In short, usefulness, opportunity and an apparently excessive learning curve. We believe this is a highly ethnocentric perception which focuses more on the fear of the unknown than on actual pragmatic hypotheses. Similarly, this work also reveals that a large part of Internet and SN users believes that despite having insufficient knowledge of these technologies, they still use them. This shows that a low perception of usage skills applied to this technology does not mean the latter will not be used. Therefore, it is initially a matter of informing on Internet and SN usefulness so as to promote interest and train people to facilitate their usage. In the case of our STP, efforts should be made in the districts because knowledge and usage in those areas is lower than in the urban center.

It is surprising that Internet users do not use this technology frequently, whereas SN users mention they access them every day.
This result leads us to conclude that the individuals who overcome access barriers become regular users, although their use is mostly limited to two activities: search for information (Internet) and contact with family and friends (SN)

Another relevant finding is the fact that individuals who use the Internet and SN prefer mobile access, mainly via their smart phones. The high penetration level of this technology in Spanish households, as well as its versatility and user friendliness, have favored its introduction as a key $\mathrm{SN}$ access and connection tool. Furthermore, since smart phones are the preferred device of our STP, we also recommend the development of specific mobile applications for this population group.

The most popular SN amongst our STP is Whatsapp; in fact, it is the only one used for a large percentage of users who do not know other applications commonly used by younger age groups (Facebook and Twitter). As already mentioned, the main purpose of usage is connecting with family and friends. With regards to this, it is important for Public Administrations and private organizations interested in this target group to promote communication through this application.

It is clear that our STP demands training and information to start using the SN. In fact, their lack of interest in these technologies is the logical consequence of their lack of knowledge, meaning economic aspects (cheaper connections, please and public networks) take a second place. It seems reasonable not to worry about the cost of services with a usefulness that is not clear. Thus, we recommend public administrations to promote Internet and SN access amongst our target age group, informing individuals on the advantages resulting from their usage. As this study reveals, people who know the Internet and SN are interested and willing to use them, with a large percentage of them saying their user skills are 
insufficient. It is important to point out that these technologies can stretch out much further than social relationships with family and pertainance groups (exchanging pictures, making videoconferences, keeping in touch with family and friends...). Limiting the Internet and SN to these activities is ignoring a much larger set of options potentially enhancing their quality of life: making appointments with their health centers, establishing direct contact with their GPs, having a detailed calendar of their drug intake, managing banking and administrative proceedings, looking for information and leisure options, etc. Once training and information problems have been solved, it would be necessary to reduce connection costs and to develop public network and access places so as to generalize their usage amongst this STP.

\section{Funds}

This research, referenced PMAFI-20-12, was carried out within the framework of a project funded by UCAM (Catholic University of Murcia) under the name "Analysis of institutional and marketing communication consumption through the Internet, mobile devices and social media" (original in Spanish).

\section{REFERENCES}

- Agudo, S., Pascual, Ma Á., \& Fombona, J. (2012). Use of digital tools amongst senior citizens (Original in Spanish). Comunicar, 39 (XX). 193-201. DOl: http:// dx.doi.org/10.3916/C39-2012-03-10.

- Aunión, J. A. (2014). There are no children in the park (Original in Spanish). El País, 06-07- 2014. (http://goo.gl/b7uhm0) (14/10/14).

- Campos Freire, Francisco (2014), Research and management of digital social networks (Original in Spanish). Panóptico 01, 7-51. La Laguna (Tenerife): La Laguna University. DOI: 10.4185/CAC 50

- Cárdenas-Corredor, D. C., Melenge-Díaz, B., Pinilla, J., Carrillo-González, G. M., \& Chaparro-Díaz, L. (2010). Social foundation of ICT usage for caretakers of people with chronic illnesses: a state of the art (Original in Spanish). Aquichan, 3 (10). 204-213. (http://goo.gl/MYa51w) (20/06/15).

- Casado-Muñoz, R., Lezcano, F., \& Rodríguez-Conde, M. J. (2015). Active aging and technology access: An evolutionary empirical study (Original in Spanish). Comunicar, 45 (XXIII). 37-46. DOI: http:// dx.doi.org/10.3916/C45-2015-04

- Castellano Fuentes, C. L. (2014). The influence of social support in the emotional state and attitudes towards old age and aging in a sample of senior citizens (Original in Spanish). International Journal of Psychology and Psychological Therapy, 3 (14). 365-377. (http://goo.gl/ hWe95q) (27/07/15).

- Regional Statistics Center of Murcia CREM (2014). Municipal Register of Inhabitants (Original in Spanish). (http:// goo.gl/W3ZQDr men and http://goo.gl/ M5twh8, women) (28/3/15).

- Chen, Y., Lee, B., \& Kirk, R.M. (2013). Internet Use among Older Adults: Constraints and Opportunities. In R. Zheng, R. Hill \& M. Gardner (Eds.). Engaging Older Adults with Modern Technology: Internet Use and Information Access Needs. (pp. 124-141). Hershey, PA: Information Science Reference. DOI: http:// dx.doi.org/10.4018/978-1-4666-1966-1. ch007

- Chen, K., \& Chan, A.H. (2014). Predictors of Gerontechnology Acceptance by Older Hong Kong Chinese. Technovation, 34(2), 126-135. DOI: http://dx.doi.org/10.1016/j.technovation.2013.09.010

- Colombo, F., Aroldi, P., \& Carlo, S. (2015). New senior citizens, new gaps: ICT, inequalities and wellbeing of senior citizens in Italy. Comunicar, 45 (XXIII). 47-55. DOl: http://dx.doi.org/10.3916/ C45-2015-05

- National Commission on Markets and Competition (2015). Characterization of some over-the-top- service uses in Spain (Electronic Communications and Audiovisual Services) (Original in Spanish). (http://goo.gl/ypRKbJ) (15/7/15) 
- Cristóbal-Fransi, E., Daries-Ramon, N., \& Baldomar, J. P. (2014). Categorization of e-consumers: an applied study based on Internet usage prospects (Original in Spanish). Cuadernos de Gestión, 1 (14). 33-55. (http://goo.gl/Mfrt3h) (21/5/15)

- Dillon, W., Madden, T., \& Firtle, N. (1996). Market research in a marketing environment. Madrid: McGraw-Hill.

- Fundación Telefónica (2011-2015). Information Society Report in Spain. (http:// goo.gl/Ily2EB) (18/4/15).

- Fundación Vodafone España (2012). ICT: senior citizens connected to the future. Executive summary. (http://goo.gl/qHgcGb) $(25 / 5 / 15)$.

- Grande, I., \& Abascal, E. (2011). Commercial research techniques and fundamentals (Original in Spanish). Madrid: ESIC.

- González, A., Ramírez, M. P., \& Viadel, V. (2012). Attitudes of the Elderly Toward Information and Communications Technologies. Educational Gerontology, 38 (9) (Original in Spanish). 585-594. DOI: 10.1080/03601277.2011.595314.

- González-Oñate, C., Fanjul-Peyró, C., \& Cabezuelo-Lorenzo, F. (2015). Use, consumption and knowledge of new technologies amongst senior citizens in France, Spain and the United Kingdom (Original in Spanish). Comunicar, 45 (XXIII), 19-28. DOI: http://dx.doi. org/10.3916/C45-2015-02

- Gracia, E., \& Herrero, J. (2008). Digital gap and quality of life amongst senior citizens (Original in Spanish). Madrid: IMSERSO. (http://goo.gl/uZJkue) (15/5/15).

- IMSERSO (2011). White book on Active Aging (Original in Spanish). Madrid: Imserso. (http://goo.gl/iKEwAa) (15/5/15).

- INE (2014). Register. Population per municipalities (Original in Spanish); (http:// goo.gl/kMGhLX) (22/9/15).

- INE (2014). Equipment and Use of Information and Communication Technologies in households (Original in Spanish). (http://goo.gl/xVOrvx) (21/4/15).

- INTECO y AGDP (2009). Study on data privacy and information security in onli- ne social networks. National Institute for Communication Technologies and Spanish Agency of Data Protection (Original in Spanish). (https://goo.gl/QnYMC2) $(18 / 3 / 15)$.

- IAB Spain $(2013,2014)$, 4th and 5th yearly study on Social Networks (Original in Spanish). (http://goo.gl/gM9ExG) y (http://goo.gl/ZPGg15) (15/4/15).

- Lelkes, Orsolya (2012). Happier and less isolated: internet use in old age. European Centre for Social Welfare Policy and Research. (http://goo.gl/mLmg9e) (15/3/15).

- Llorente-Barroso, C., Viñarás-Abad, M., \& Sánchez-Valle, M. (2015). Senior citizens and the Internet: The Net as a source of opportunities for active aging (Original in Spanish). Comunicar, 45 (XXIII). 29-36. DOI: http://dx.doi.org/10.3916/ C45-2015-03

- Luna-García, H., Mendoza-González, R., \& Álvarez-Rodríguez, F. J. (2015). Design patterns intended to facilitate access and use of social applications amongst senior citizens (Original in Spanish). Comunicar, 45 (XXIII). 85-94. http://dx.doi. org/10.3916/C45-2015-09

- Malhotra, N. (2004). Market research: an applied approach (4 Ed.) (Original in Spanish). Mexico: Prentice Hall.

- Marketingdirecto.com (2014). Spain is the fourth most popular country in terms of WhatsApp usage (Original in Spanish). (http://goo.gl/zxPRLU) (15/5/15).

- Observatorio Fundación Vodafone-CERMI (2011). Current status of accessibility to information and communication technologies (ICTs) Madrid (Original in Spanish): (http://goo.gl/DvBF82) (15/8/15).

- ONTSI (2011). Social Networks in the Internet (Original in Spanish). (http://goo. $\mathrm{gl} / \mathrm{mH} 67 \mathrm{dA})(2 / 7 / 15)$.

- Padilla-Góngora, D., \& Padilla-Clemente, A. M. (2008). Technologies for senior citizens (Original in Spanish). Universitas Psychologica, 3 (7). 883-894. (http:// goo.gl/2dS7ts) (28/07/15)

- Pew Research Center (2015). Demographics of Key Social Networking Platfor- 
ms. (http://goo.gl/W4yVNN) (15/7/15).

- Peral-Peral, B., Arenas-Gaitán, R., \& Villarejo-Ramos, A. F. (2015). From a digital gap to a psycho-digital gap: Senior citizens and social networks (Original in Spanish). Comunicar, 45 (XXIII). 5764. DOI: http://dx.doi.org/10.3916/C452015-06

- Red.es y Fundación Vodafone España (2014). Technologies oriented to mobility: assessment and trends (Original in Spanish). (http://goo.gl/faOM4L) (15/6/15).

- Sánchez, M., Kaplan, M. S., \& Bradley, L. (2015). Using technology to interconnect generations: considerations on form and function (Original in Spanish). Comunicar, 45 (XXIII). 95-104. DOl: http://dx.doi. org/10.3916/C45-2015-10

- The Cocktail Analysis y Arena (2014). VI Wave of the Social Network Observatory (Original in Spanish). (http://goo. gl/QallV5) (13/5/15).
1. INE hereafter.

2. Hereafter referred to as SN.

3. Some studies consulted (Leikes, 2012; González, 4. Ramírez \& Viadel, 2012; González, Fanjul, \& Cabezuelo, 2015) refer to individuals over 65 years of age. However, with the aim of ensuring accuracy, retired people in the municipality of Murcia will be referred to as senior citizens over the age of 64 because the legal retirement age is 65 .

5. ONTSI hereafter.

6. From now on, we will refer to this population as STP (Study Target Population).

7. It is important to notice than SN percentages are referred to Internet users, not all STP.

(1) Information refers to explanations regarding SN uses and functionalities for them. 
